\title{
Animal performance and carcass characteristics from confined lambs fed on concentrate feed and additives
}

\author{
TAYRONE F. PRADO ${ }^{1}$, ALDI F.S. FRANÇA ${ }^{2}$, MARIA LÚCIA G. MEIRINHOS ${ }^{2}$, HUGO J.M.C. PERON ${ }^{1}$, \\ REGINALDO N. FERREIRA ${ }^{3}$, LEONARDO G. OLIVEIRA ${ }^{1}$ and DANIEL S. CORRÊA ${ }^{1}$ \\ ${ }^{1}$ Programa de Pós-Graduação em Ciência Animal, Universidade Federal de Goiás, Av. \\ Esperança, s/n, Campus II, Samambaia, 74690-900 Goiânia, GO, Brasil \\ ${ }^{2}$ Departamento de Produção Animal, Universidade Federal de Goiás, Av. Esperança, \\ s/n, Campus II, Samambaia, 74690-900 Goiânia, GO, Brasil \\ ${ }^{3}$ Instituto de Ciências Biológicas, Universidade Federal de Goiás, Rodovia GO - 080, \\ Km 13, Campus II, Samambaia, 74001-970 Goiânia, GO, Brasil
}

Manuscript received on August 13, 2014; accepted for publication on February 4, 2015

\begin{abstract}
The number of sheep flocks in Brazil is increasing. It is known that lambs must be slaughtered when young for producing quality meat. The current study evaluated the inclusion of protected methionine, protected lysine, lysophospholipid and amylolytic enzymes in a diet to lambs and their effects on weight gain and quantitative carcass traits at slaughtering. Eighty non-castrated male crossbred Dorper x Santa Inês lambs, $20.57 \pm 4.33 \mathrm{~kg}$ live weight, were used. The feedlot lasted 64 days and 60 animals were slaughtered. There were no differences for live weight, daily feed intake, feed conversion and average daily weight gain at the first 28 days of feedlot. From the $28^{\text {th }}$ day lysophospholipid treatment presented the highest live weight. Lysophospholipid and amylolytic enzyme presented the best performance in average daily gain, followed by protected methionine, control and protected lysine. Lysophospholipid treatment presented higher daily feed intake rates than protected lysine and protected methionine. Feed conversion was lower for amylolytic enzyme and higher for control. No changing in carcass traits was reported due to additives. Better performance may be achieved with feedlot lambs fed on diets with the addition of amylolytic enzyme and lysophospholipid at the finishing phase.
\end{abstract}

Key words: amylolytic enzyme, lysine, lysophospholipid, methionine, ovine.

\section{INTRODUCTION}

The Brazilian sheep herd lies at approximately 17.4 million and data from the Brazilian Institute of Geography and Statistics (IBGE) show a countrywide rising trend in sheep production during the last decades (IBGE 2010).

Correspondence to: Daniel Staciarini Corrêa

E-mail: daniel.staciarini@terra.com.br
Since sheep and goats, among ruminants, have the smallest interval between birth and slaughter (Soares et al. 2012), this fact should be underpinned as an opportunity to produce quality meat intensively. In fact, young animals have better meat quality and feed efficiency (Macedo et al. 2007).

The confinement of sheep is an interesting alternative for management, and aims at providing 
a standardized product of excellent quality throughout the year. However, the system requires more investments in electric energy, infrastructure and labor (Soares et al. 2012). So that sheep confinement could be made viable, sheep breeds or crosses, either specialized in meat production and food additives or with better zootechnical performances, should be acquired.

Methionine and lysine are essential amino acids for ruminants (NRC 2001) and are considered the main limiting factors in livestock production (Sun et al. 2007). A deficit exists between the amount of amino acids supplied by the diet and the amount demanded by the animal. Consequently, amino acid supplementation will surely lead to improvements in the animal efficiency.

Amylases are enzymes responsible for the digestion of various polysaccharides. Their inclusion in diets with high starch concentration could reduce nutrient losses through feces and increase the availability of energy for animal production (Tricarico et al. 2008).

Lysophospholipids are natural biosurfactants that help in the absorption of lipids (Silva Jr. 2009). Their use provides a greater amount of energy and animal growth in the termination period due to higher feed efficiency. The deposition of fat in the carcass as adipose tissue is more efficient in retaining energy than protein deposition in muscle tissue (Garrett 1980). However, it is more costly, since it has low water content when compared to muscle tissue. Since meat is commercialized according to weight, fat deposition on the carcass raises costs within the production system. However, a minimum cover of carcass fat is recommended to avoid damage to the substrate during post-slaughter cooling.

The assay evaluated the inclusion of protected methionine, protected lysine, lysophospholipid and amylolytic enzymes in a diet based on corn and cottonseed meal for feedlot lambs, and their effects on weight gain and carcass quantitative characteristics at slaughter.

\section{MATERIALS AND METHODS}

All proceedings in this study were approved by the Universidade Federal de Goiás' Ethics Committee on Animal Use, where the study is registered under the number 37288; available at http://ceua. prpg.ufg.br/pages/34676-principios-eticos-naexperimentacao-animal.

Eighty non-castrated lambs, strain Santa Inês x Dorper, with $20.57 \pm 4.33 \mathrm{~kg}$ live weight were used. The lambs were born in June and July 2011 and were kept on grass pastures (Brachiaria brizantha) with access to creep feeding until weaning in October 2011. Animals were housed in twenty 8 $\mathrm{m}^{2}$ collective pens, with four lambs in each pen, in a shed with cemented floor. The experimental shed belongs to the School of Veterinary and Animal Science, of the Federal University of Goiás, Goiânia-GO, Brazil. Each pen was supplied with a water trough and a $0.3 \mathrm{~m}$ feeder for each animal.

The pens were randomly assigned for five treatments: control (CON), amylase enzyme (ENZ), protected lysine (LYS), lysophospholipids (LYP) and protected methionine (MET), with four stalls per treatment. Each pen consisted of a different treatment. So the trial was composed by five treatments, with four repetitions (pens) and four animals in each pen (16 animals in each treatment).

The amylolytic enzyme was produced from the fungus Aspergillus awamori and used in lyophilized form at a dosage of $16.9 \mathrm{U} / \mathrm{kg}$ diet as feed. The production, characterization and enzymatic evaluation were performed at the Laboratory of Enzymology and Digestion Physiology of the Institute for Biological Sciences, Federal University of Goiás, Goiânia, GO Brazil. Amylase activity was determined by measuring 
reduced sugar produced in an enzymatic reaction (Miller 1959). Protected methionine was supplied by MetiPEARL $\AA$ product $(55.3 \%$ methionine, Kemin) and the protected lysine by LysiPEARL ${ }^{\circledR}$ (48.5\% L-lysine hydrochloride, Kemin). The lysophospholipid came from Lysoforte Booster Dry ${ }^{\circledR}$ (Kemin).

Experimental diets were provided twice a day, at 7 am and $5 \mathrm{pm}$, with supply adjusted daily to achieve up to $10 \%$ leftover of the amount offered. Food provided and leftovers were weighed daily. The diets were fed in a total mixed ration and were formulated to meet the nutritional demands of growing lambs to an average daily gain of $300 \mathrm{~g} /$ day per animal, following NRC (2007). Additives were added to control diet in the formulation of the experimental diets. Table I shows the percentage of inclusion of ingredients and chemical composition of diets for crude protein (CP), ether extract (EE), neutral detergent fiber (NDF), acid detergent fiber (ADF) and mineral matter (MM).

Animals were always weighed at 8 am, without fasting at different time intervals. At the end the experiment (64 confinement days) the animals were slaughtered in a slaughterhouse after a 21 -h fasting period, following standard procedures: stunning, bleeding, skinning, evisceration and splitting of the carcass in halves. Half-carcasses were kept in a refrigerator for $24 \mathrm{~h}$, at $4{ }^{\circ} \mathrm{C}$.

Medium daily gain (MDG) was determined in the intervals (from zero to 28 days; from 28 to 64 days; for the total confinement period) and was calculated by dividing the weight gain of each animal per time period. Daily feed intake (DFI) was obtained by subtracting the quantity supplied and the quantity of leftovers weighed daily for each period in each bay. Feed conversion (FC) was calculated by dividing total feed intake by total weight gain in each period and for each pen.

TABLE I

Diet composition and chemical composition of diets from confined Dorper $x$ Santa Inês lambs with high concentrate diet (CON) plus amylolytic enzyme (ENZ), protected lysine (LYS), lysophospholipid (LYP) and protected methionine (MET).

\begin{tabular}{|c|c|c|c|c|c|}
\hline \multirow{2}{*}{ Ingredients } & \multicolumn{5}{|c|}{ Treatments } \\
\hline & $\mathrm{CON}$ & ENZ & LYS & LYP & MET \\
\hline \multicolumn{6}{|c|}{ Diet composition } \\
\hline Cottonseed pie (g/kg) & 550.0 & 550.0 & 550.0 & 550.0 & 550.0 \\
\hline Corn grain $(\mathrm{g} / \mathrm{kg})$ & 420.0 & 420.0 & 417.0 & 420.0 & 419.0 \\
\hline Minerals and vitamin premix* $(\mathrm{g} / \mathrm{kg})$ & 30.0 & 30.0 & 30.0 & 30.0 & 30.0 \\
\hline Enzyme (g/kg) & - & 0.760 & - & - & - \\
\hline Lysine (g/kg) & 0.845 & 0.845 & 1.183 & 0.845 & 0.845 \\
\hline Lysophospholipid (g/kg) & - & - & - & 0.380 & - \\
\hline Methionine (g/kg) & 0.425 & 0.425 & 0.425 & 0.425 & 1.555 \\
\hline \multicolumn{6}{|c|}{ Chemical Composition } \\
\hline Dry matter $(\mathrm{DM})(\mathrm{g} / \mathrm{kg})$ & 905.0 & 905.0 & 905.0 & 905.0 & 905.0 \\
\hline $\mathrm{CP}(\mathrm{g} / \mathrm{kg}$ of $\mathrm{DM})$ & 201.1 & 201.1 & 201.1 & 201.1 & 201.1 \\
\hline $\mathrm{EE}(\mathrm{g} / \mathrm{kg}$ of $\mathrm{DM})$ & 74.1 & 74.1 & 74.1 & 74.1 & 74.1 \\
\hline $\mathrm{NDF}(\mathrm{g} / \mathrm{kg}$ of $\mathrm{DM})$ & 342.3 & 342.3 & 342.3 & 342.3 & 342.3 \\
\hline $\mathrm{ADF}(\mathrm{g} / \mathrm{kg}$ of $\mathrm{DM})$ & 215.0 & 215.0 & 215.0 & 215.0 & 215.0 \\
\hline $\mathrm{MM}(\mathrm{g} / \mathrm{kg}$ of $\mathrm{DM})$ & 65.2 & 65.2 & 65.2 & 65.2 & 65.2 \\
\hline
\end{tabular}

*Nutrient/kg Minerals and vitamin premix: Calcium = $262 \mathrm{~g} ;$ Phosphorus = $60 \mathrm{~g}$; Sulfur = $50 \mathrm{~g}$; Magnesium = $40 \mathrm{~g}$; Sodium = $30 \mathrm{~g}$; Iron = 3,000 mg; Zinc $=1000 \mathrm{mg}$; Manganese $=900 \mathrm{mg}$; Fluoride $=600 \mathrm{mg}$; Copper = $221 \mathrm{mg}$; Iodine $=15 \mathrm{mg} ;$ Selenium $=10 \mathrm{mg} ;$ Cobalt $=5 \mathrm{mg}$. 
Sixty animals were slaughtered. Slaughter weight (SW) was considered the same as the last weight of confinement since it was impossible to weigh the animals at slaughter. After slaughter, the half-carcasses were weighed to obtain hot carcass weight $(\mathrm{HCW})$ and to calculate hot carcass yield $(\mathrm{HCY})$; $\left(\mathrm{HCY}=\mathrm{HCW} / \mathrm{SW}^{*} 100\right)$. After $24 \mathrm{~h}$ under refrigeration, the half-carcasses were weighted again to obtain cold carcass weight $(\mathrm{CCW})$ and to calculate cold carcass yield $(\mathrm{CCY}) ;(\mathrm{CCY}=\mathrm{CCW} /$ $\mathrm{SW}^{*} 100$ ) and weight loss by cooling (WLC); $\left[\mathrm{WLC}=(\mathrm{HCW}-\mathrm{CCW} / \mathrm{HCW})^{*} 100\right]$.

Two completely randomized designs (CRD) in different arrangements were performed. A split plot design was used for feedlot performance. For the variables, body weight (BW), MDG, DFI and FC, the stall was the experimental unit. For testing the lambs' quantitative carcass traits, WS was used as a covariate, with each animal being an experimental unit.

Data were analyzed with statistical package Easyanova (Arnhold 2013) of R statistical program (R Development Core Team 2012).

\section{RESULTS}

\section{ANIMAL PERFORMANCE}

The results for the variables: body weight (BW), mean daily gain (MDG), daily feed intake (DFI) and feed conversion (FC), are shown in Table II. All variables were analyzed for the interval from 0 to 28 days, 28 to 64 days and for the total period. There was no difference between treatments for all variables during the first period.

Animals' BW increased significantly over time, or rather, from $20.57 \pm 4.33 \mathrm{~kg}$ at the beginning of the experiment to up to $35.85 \pm 7.50 \mathrm{~kg}$ on the $64^{\text {th }}$

TABLE II

Body weight (BW), mean daily gain (MDG), average daily feed intake (DFI) and feed conversion (FC) of confined Dorper x Santa Inês lambs with high concentrate diet (CON) plus amylolytic enzyme (ENZ), protected lysine (LYS), lysophospholipid (LYP) and protected methionine (MET).

\begin{tabular}{|c|c|c|c|c|c|c|c|c|c|}
\hline \multirow{2}{*}{$\begin{array}{l}\text { Time } \\
\text { (days) }\end{array}$} & \multicolumn{5}{|c|}{ Treatments } & \multirow{2}{*}{ Mean } & \multirow{2}{*}{$\mathrm{P} 1 *$} & \multirow{2}{*}{$\mathrm{P} 2 * *$} & \multirow{2}{*}{$\mathrm{P} 3 * * *$} \\
\hline & $\mathrm{CON}$ & ENZ & LYS & LYP & MET & & & & \\
\hline \multicolumn{10}{|c|}{$\mathrm{BW}(\mathrm{kg})$} \\
\hline 0 & $20.89^{\mathrm{aC}}$ & $20.49^{\mathrm{aC}}$ & $20.18^{\mathrm{aC}}$ & $20.98^{\mathrm{aC}}$ & $20.31^{\mathrm{aC}}$ & $20.57^{\mathrm{C}}$ & \multirow{4}{*}{0.0137} & \multirow{4}{*}{$<0.0001$} & \multirow{4}{*}{$<0.0001$} \\
\hline 28 & $28.53^{\mathrm{aB}}$ & $28.25^{\mathrm{aB}}$ & $27.34^{\mathrm{aB}}$ & $28.67^{\mathrm{aB}}$ & $28.37^{\mathrm{aB}}$ & $28.23^{\mathrm{B}}$ & & & \\
\hline 64 & $35.27^{\mathrm{bcA}}$ & $36.75^{\mathrm{abA}}$ & $33.80^{\mathrm{cA}}$ & $37.77^{\mathrm{aA}}$ & $35.65^{\mathrm{bA}}$ & $35.85^{\mathrm{A}}$ & & & \\
\hline Mean & $28.23^{\mathrm{ab}}$ & $28.50^{\mathrm{ab}}$ & $27.10^{\mathrm{b}}$ & $29.14^{\mathrm{a}}$ & $28.11^{\mathrm{ab}}$ & & & & \\
\hline \multicolumn{10}{|c|}{$\operatorname{MDG}\left(\mathrm{kg} \mathrm{day}^{-1}\right)$} \\
\hline $0-28$ & $0.273^{\mathrm{aA}}$ & $0.278^{\mathrm{aA}}$ & $0.256^{\mathrm{aA}}$ & $0.275^{\mathrm{aA}}$ & $0.288^{\mathrm{aA}}$ & $0.274^{\mathrm{A}}$ & & & \\
\hline $28-64$ & $0.187^{\mathrm{cB}}$ & $0.236^{\mathrm{abB}}$ & $0.179^{\mathrm{cB}}$ & $0.253^{\mathrm{aA}}$ & $0.202^{\mathrm{bcB}}$ & $0.211^{\mathrm{B}}$ & 0.0022 & $<0.0001$ & 0.0097 \\
\hline $0-64$ & $0.224^{\mathrm{bc}}$ & $0.254^{\mathrm{a}}$ & $0.213^{\mathrm{c}}$ & $0.262^{\mathrm{a}}$ & $0.240^{\mathrm{ab}}$ & & & & \\
\hline \multicolumn{10}{|c|}{$\mathrm{FC}\left(\mathrm{kg} \mathrm{kg}^{-1}\right)$} \\
\hline $0-28$ & $4.45^{\mathrm{aB}}$ & $4.40^{\mathrm{aB}}$ & $4.45^{\mathrm{aB}}$ & $4.43^{\mathrm{aB}}$ & $4.17^{\mathrm{aB}}$ & $4.38^{\mathrm{B}}$ & & & \\
\hline $28-64$ & $6.93^{\mathrm{aA}}$ & $5.56^{\mathrm{cA}}$ & $6.43^{\mathrm{abA}}$ & $5.84^{\mathrm{bcA}}$ & $6.10^{\mathrm{bcA}}$ & $6.17^{\mathrm{A}}$ & 0.0105 & $<0.0001$ & 0.0209 \\
\hline $0-64$ & $5.60^{\mathrm{a}}$ & $5.00^{\mathrm{b}}$ & $5.38^{\mathrm{ab}}$ & $5.18^{\mathrm{ab}}$ & $5.08^{\mathrm{ab}}$ & & & & \\
\hline \multicolumn{10}{|c|}{ DFI $\left(\mathrm{kg} \mathrm{day}^{-1}\right)$} \\
\hline $0-28$ & $1.204^{\mathrm{aA}}$ & $1.217^{\mathrm{aA}}$ & $1.134^{\mathrm{aA}}$ & $1.210^{\mathrm{aB}}$ & $1.198^{\mathrm{aA}}$ & $1.193^{\mathrm{B}}$ & & & \\
\hline $28-64$ & $1.295^{\mathrm{bA}}$ & $1.307^{\mathrm{bA}}$ & $1.153^{\mathrm{cA}}$ & $1.476^{\mathrm{aA}}$ & $1.228^{\mathrm{bcA}}$ & $1.292^{\mathrm{A}}$ & 0.0051 & $<0.0001$ & $<0.0001$ \\
\hline $0-64$ & $1.255^{\mathrm{ab}}$ & $1.268^{\mathrm{ab}}$ & $1.145^{\mathrm{b}}$ & $1.360^{\mathrm{a}}$ & $1.214^{\mathrm{b}}$ & & & & \\
\hline
\end{tabular}

Means followed by different lowercase letters in lines or uppercase letters in columns differ by Tukey's test $(p<0.05)$. Analysis of variance rates of probability for treatments $(*)$, time $(* *)$ and treatment-time interaction $(* * *)$. 
day. The same occurred in all treatments. However, in the final period, LYP treatment had the highest BW, followed by ENZ, MET, CON and LYS. LYS treatment had the worst performance of all.

As for the MDG, there were differences in the averages for the second termination period (28-64 days). LYP treatment $(\mathrm{p}<0.05)$ had the highest rate, followed by ENZ, MET, CON and LYS. Treatments CON and LYS presented the worst performance in this period. MDG decreased from the first to the second period in all treatments except in LYP, which kept MDG similar to that of the first period (0-28 days).

Daily feed intake (DFI) increased $(\mathrm{p}<0.05)$ from the first to the second period when confinement, as a whole, was analyzed. However, there was a significant increase in DFI only for LYP between these two periods. In the second period the DFI was higher for LYP, followed by ENZ, CON, MET and LYS.

\section{CARCASS CHARACTERISTICS}

No significant differences ( $p>0.05$ ) were observed in the characteristics related to slaughter and carcasses. Results are shown in Table III.

Table IV shows correlations between carcasses variables (values above main diagonal) and the probability values for correlations of these variables (values below main diagonal).

TABLE III

Characteristics of carcasses from confined Dorper $x$ Santa Inês lambs with high concentrate diet (CON) plus amylolytic enzyme (ENZ), protected lysine (LYS), lysophospholipid (LYP) and protected methionine (MET).

\begin{tabular}{|c|c|c|c|c|c|c|c|c|}
\hline \multirow{2}{*}{ Variable } & \multicolumn{5}{|c|}{ Treatments } & \multirow{2}{*}{ Mean } & \multirow{2}{*}{$\mathrm{P}$} & \multirow{2}{*}{ CV $(\%$} \\
\hline & $\mathrm{CON}$ & ENZ & LYS & LYP & MET & & & \\
\hline SW (kg) & 34.82 & 35.51 & 38.18 & 35.99 & 34.67 & 35.83 & 0.7179 & 17.43 \\
\hline HCW (kg) & 17.88 & 18.24 & 18.36 & 17.98 & 18.30 & 18.15 & 0.5194 & 4.17 \\
\hline $\mathrm{HCY}(\mathrm{g} / \mathrm{kg})$ & 50.27 & 51.34 & 51.55 & 50.59 & 51.42 & 51.04 & 0.5572 & 4.21 \\
\hline CCW (kg) & 17.44 & 17.68 & 17.83 & 17.41 & 17.83 & 17.64 & 0.4474 & 4.07 \\
\hline CCY (g/kg) & 49.00 & 49.69 & 50.02 & 48.91 & 50.04 & 49.53 & 0.5390 & 4.21 \\
\hline WLC $(\mathrm{g} / \mathrm{kg})$ & 2.61 & 3.22 & 2.65 & 3.26 & 2.79 & 2.91 & 0.7183 & 49.30 \\
\hline
\end{tabular}

(SW) Slaughter weight; (HCW) hot carcass weight; (HCY) hot carcass yield; (CCW) cold carcass weight; (CCY) cold carcass yield; (WLC) weight loss by cooling; (CV) coefficient of variation.

TABLE IV

Correlations (above diagonal) probability values by $\mathbf{t}$ test (below diagonal) for the characteristics of carcasses of Dorper x Santa Inês lambs with high concentrate diet (CON) plus amylolytic enzyme (ENZ), protected lysine (LYS), lysophospholipid (LYP) and protected methionine (MET).

\begin{tabular}{ccccccc}
\hline & SW & HCW & HCY & CCW & CCY & WLC \\
\hline SW & $\mathbf{1 , 0 0 0}$ & 0.966 & -0.387 & 0.970 & -0.255 & 0.459 \\
HCW & $<0.001$ & $\mathbf{1 , 0 0 0}$ & -0.137 & 0.997 & -0.010 & 0.393 \\
HCY & 0.003 & 0.300 & $\mathbf{1 , 0 0 0}$ & -0.164 & 0.945 & -0.372 \\
CCW & $<0.001$ & $<0.001$ & 0.215 & $\mathbf{1 , 0 0 0}$ & -0.015 & 0.461 \\
CCY & 0.050 & 0.938 & $<0.001$ & 0.911 & $\mathbf{1 , 0 0 0}$ & -0.048 \\
WLC & $<0.001$ & 0.002 & 0.004 & $<0.001$ & 0.718 & $\mathbf{1 , 0 0 0}$ \\
\hline
\end{tabular}

When the probability value (p) is less than 0.05 , the correlation is significantly different from zero. Slaughter weight (SW); hot carcass weight (HCW); hot carcass yield (HCY); cold carcass weight (CCW); cold carcass yield (CCY); weight loss by cooling (WLC). 


\section{DISCUSSION}

\section{ANIMAL PERFORMANCE}

Feed conversion $(\mathrm{FC})$ increased $(\mathrm{p}<0.05)$ in all treatments from the first $(0-28)$ to the second (2864 days) termination period. Best FC was achieved by the ENZ treatment at the second period; LYS and CON had the worst results. When analyzing the total experimental period, the best FC was achieved by treatment ENZ and the worse by CON, without any difference in the other treatments.

Diets containing amino acids (LYS or MET) presented the lowest DFI during the experimental period. Analysis of DFI throughout the confinement showed significant differences among treatments LYP, MET and LYS, in which the two latter were lower than the first.

Furusho-Garcia et al. (2010) reported MDG at $214 \mathrm{~g}$ for confined Dorper x Santa Inês lambs, or rather, a lower rate than that of the current experiment throughout the total period. The diet evaluated, comprised $300 \mathrm{~g} / \mathrm{kg}$ Tifton hay (Cynodon dactylon), $516 \mathrm{~g} / \mathrm{kg}$ of ground corn and $165 \mathrm{~g} / \mathrm{kg}$ soybean meal.

Several authors included MET and LYS for lambs and found different results for MDG, DFI, FC and BW. Results are given below. Acosta et al. (2012) added MET in diets based on corn stover for Creoles lambs and observed no improvement in MDG, featuring lower values than those of the current study ( $84 \mathrm{~g}$ and $67 \mathrm{~g}$ respectively with and without MET). Inferior quality diets would possibly not enable significant MDG since DFI was also lower $(0.869 \mathrm{~kg}$ and $0.901 \mathrm{~kg}$ respectively with and without MET).

Obeidat et al. (2008) included 7.0 or $14.0 \mathrm{~g} /$ day MET for Awassi lambs (16.8 kg BW) and reported no difference in DFI $(1.122 ; 1.040 ; 1.029 \mathrm{~kg})$; in BW (38.3; 37.3; $37.2 \mathrm{~kg})$; in MDG (251; 238; $237 \mathrm{~g})$ and in $\mathrm{FC}(4.49 ; 4.39 ; 4.35)$, respectively, for the treatments control, $7.0 \mathrm{~g}$ MET and $14.0 \mathrm{~g}$ MET. Similar results were registered by Wiese et al. (2003) who included 1.0, 2.0, 3.0, 4.0 or $5.0 \mathrm{~g}$ of MET in the diets of Merino, Poll Dorset or Merino $\mathrm{x}$ Poll Dorset lambs.

Baldwin et al. (1993) reported 315, 306 and $317 \mathrm{~g}$ MDG respectively for inclusion of 0,1 or $2 \mathrm{~g} / \mathrm{kg}$ MET in the diet of Dorset sheep on the twelfth week of age (16.9 $\mathrm{kg} \mathrm{BW})$. DFIs were $1.195,1.202$ and $1.192 \mathrm{~kg}$ for treatments 0,1 and $2 \mathrm{~g} / \mathrm{kg}$ MET and FCs were 3.98, 4.32 and 3.94 for treatments 0,1 and $2 \mathrm{~g} / \mathrm{kg}$ MET, respectively, with no significant difference. Differences were not found in Appenninica lambs receiving LYS and MET associated in different doses and ratios (Antongiovanni et al. 2002).

Imik and Gunlu (2011) evaluated Morkaraman lambs (2.5 months old and $29.5 \mathrm{~kg} \mathrm{BW})$ which received diet with $2 \mathrm{~g} / \mathrm{kg}$ MET and found differences between treatments. In treatments with MET, MDG and DFI were $381.22 \mathrm{~g}$ and $1.87 \mathrm{~kg}$, respectively, whereas in control treatment, MDG and DFI were $318.57 \mathrm{~g}$ and $1.54 \mathrm{~kg}$, respectively. However, FC was similar between control and MET diets (4.83 and 4.91, respectively).

In the current study, the experimental diets were protein rich and thus the dietary amino acids supply may have been sufficient to meet the lambs' demands on lysine and methionine. It has also been observed that treatments with inclusion of protected amino acids were not significantly effective in improving MDG, BW, FC and DFI when compared to control diet (CON).

In the case of ENZ inclusion, Crosby et al. (2006) studied Bacillus licheniformis' amylase in Suffolk crossbred lambs' diets and they did not report any changes in MDG or FC. Rojo-Rubio et al. (2005) also included Bacillus licheniformis and Aspergillus niger's amylases in Suffolk lambs' diet and concluded that ENZ addition did not affect DFI, MDG or FC.

Unlike the results reported by other authors, in the current study the best MDG and FC medium was obtained by ENZ treatment when compared to $\mathrm{CON}$. The above may be explained by possible 
changes caused by amylase in ruminants' digestion. These changes include polypeptide hydrolysis, increased ruminal microbial adhesion with food, stimulation of rumen microbial populations and synergism with rumen microbial enzymes (Tricarico et al. 2008).

\section{CARCASS CHARACTERISTICS}

Experimenting with confined Santa Inês and crossbred Dorper x Santa Inês lambs $(19.8 \mathrm{~kg}$ BW) fed on rations composed of $300 \mathrm{~g} / \mathrm{kg}$ Manihot pseudoglaziovii hay and $700 \mathrm{~g} / \mathrm{kg}$ concentrate, Cartaxo et al. (2009) reported HCY values of 468.2 $\mathrm{g} / \mathrm{kg}$ and $465.3 \mathrm{~g} / \mathrm{kg}$ and CCY values of $459.5 \mathrm{~g} /$ $\mathrm{kg}$ and $456.0 \mathrm{~g} / \mathrm{kg}$, respectively. These values were lower than those registered in the current assay in which average HCY and CCY rates were $510.4 \mathrm{~g} /$ $\mathrm{kg}$ and $495.3 \mathrm{~g} / \mathrm{kg}$, respectively. Furusho-Garcia et al. (2010) obtained $471.6 \mathrm{~g} / \mathrm{kg}$ and $454.4 \mathrm{~g} / \mathrm{kg}$ for CCY, similar to Cartaxo et al. (2009), but lower than the values of the current research. Furthermore, WLC reported by Furusho-Garcia et al. (2010) was $36.5 \mathrm{~g} / \mathrm{kg}$, in other words, slightly higher than the values in the current study.

Burke and Apple (2007) registered HCY values of $510.0 \mathrm{~g} / \mathrm{kg}, 471.0 \mathrm{~g} / \mathrm{kg}$ and $527.0 \mathrm{~g} / \mathrm{kg}$, respectively, for Dorper, Katahdin and Saint Croix wool-less lambs. In addition, WLC values of 66 $\mathrm{g} / \mathrm{kg}, 62 \mathrm{~g} / \mathrm{kg}$ and $62 \mathrm{~g} / \mathrm{kg}$ for the same animals, grazing on a pasture sown with ryegrass (Lolium multiflorium) and Bermuda grass (Cynodon spp.), supplemented with $0.68 \mathrm{~kg} /$ day of soybean bran and corn.

Abdelrahman (2009) evaluated Shami goatlings receiving $5.0 \mathrm{~g}$ MET daily, and found no difference in HCY $(487.3 \mathrm{~g} / \mathrm{kg}$ without MET and $479.3 \mathrm{~g} / \mathrm{kg}$ with MET). There was also no difference in the characteristics of finishing lambs' carcass, with the addition of $1.0 \mathrm{~g}$ to $5.0 \mathrm{~g}$ MET per animal/day (Wiese et al. 2003).

Obeidat et al. (2008) found no differences in Awassi lambs' HCY with 0 (507 g/kg), 7.0 (508 $\mathrm{g} / \mathrm{kg})$ or $14.0 \mathrm{~g}(501 \mathrm{~g} / \mathrm{kg}) \mathrm{MET} /$ day. However, Abdelrahman and Hunaiti (2008) evaluated Awassi lambs and reported differences in HCY due to MET inclusion. The inclusion of $2.0 \mathrm{~g}$ MET raised HCY from $538 \mathrm{~g} / \mathrm{kg}$ to $548 \mathrm{~g} / \mathrm{kg}$. Moreover, HCY was equal to $509 \mathrm{~g} / \mathrm{kg}$ when the group received $4.0 \mathrm{~g}$ MET.

HCY and CCY rates were calculated with nonfasting animals' BW. Experimenting with Dorper x Santa Inês lambs, Furusho-Garcia et al. (2010) reported $52 \mathrm{~g} / \mathrm{kg}$ loss in BW due to fasting. HCY and CCY rates reported in the current assay would have been even higher if BW were measured after fasting. These data, however, could not be obtained.

HCY and CCY data based on non-fasting BW are important factors to be evaluated at the time when purchasing or finishing animals. The Brazilian lamb meat production business, the animals to be sent for slaughter are usually weighed on the farm, without fasting, and commercialization is usually based on live BW.

BW at slaughter is an important variable due to the high positive correlation $(\mathrm{p}<0.05)$ observed between this variable and $\mathrm{HCW}$ and CCW. It is expected that a high live weight at slaughter (SW) implies heavier carcasses. Fernandes et al. (2008) found lower correlation coefficients for the same variables, namely, 0.83 for $\mathrm{HCW}$ and 0.85 for CCW. WLC rates were higher in heavier carcasses, even with low correlation coefficient.

Although HCY and CCY tended to decrease with increasing SW, they presented a weak correlation with SW in the current study. According to Silva and Pires (2000), the highest carcass yields were found in younger animals due to the increase in the gastrointestinal tract proportion in older animals.

The results provided in the current paper show that better weight gains could be achieved by confined lambs fed on diets with the addition of amylolytic enzyme and lysophospholipid in the finishing phase. 
There was no improvement in quantitative carcass traits due to the addition of amylolytic enzyme, protected lysine, methionine or protected lysophospholipid in the conditions in which the current assay was performed.

\section{RESUMO}

O número de rebanhos ovinos no Brasil está aumentando. Sabe-se que os carneiros devem ser abatidos jovens para produzirem carne de boa qualidade. O presente estudo avaliou a inclusão de metionina protegida, lisina protegida, lisofosfilipídeo e de enzimas amilolíticas em uma dieta para cordeiros e os seus efeitos sobre o ganho de peso e características quantitativas da carcaça ao abate. Foram usados oitenta cordeiros (Dorper x Santa Inês), machos não castrados, com peso vivo de 20,57 $\pm 4,33 \mathrm{~kg}$. O confinamento durou 64 dias e 60 animais foram abatidos. Não houve diferenças de peso vivo, consumo, conversão alimentar e ganho médio diário nos primeiros 28 dias de confinamento. A partir do $28^{\circ}$ dia o tratamento com lisofosfolipídeo promoveu maiores pesos corporais. Lisofosfolipídeo e enzima amilolítica apresentaram melhor resultado quanto ao ganho médio diário, seguido de metionina protegida, controle e lisina protegida. O tratamento com lisofosfolipídeo promoveu taxas de consumo diário mais altas que os com lisina protegida e metionina protegida. A conversão alimentar foi menor no tratamento enzima amilolítica e maior no tratamento controle. Nenhuma alteração nas características de carcaça pode ser atribuída aos aditivos. Melhores desempenhos de cordeiros confinados podem ser conseguidos com dietas com adição de enzima amilolítica e lisofosfolipídeo na fase de terminação

Palavras-chave: enzima amilolítica, lisina, lisofosfolipídeo, metionina, ovinos.

\section{REFERENCES}

ABDELRAHMAN MM. 2009. General performance of growing Shami kids fed high energy and protected methionine. Asian J Anim Vet Adv 4: 52-59.

ABDELRAHMAN MM AND HUNAITI DA. 2008. The effect of dietary yeast and protected methionine on performance and trace minerals status of growing Awassi lambs. Livest Sci 115: 235-241.
Acosta ES, Cerrilla MEO, Martínez GM, VAldez ODM AND DIOS SEB. 2012. Rastrojo de maíz tratado con urea y metionina protegida en dietas para ovinos en crecimiento. Interciencia 37: 395-399.

Antongiovanni M, ACCIAIOLI A, Franci O, PONZETTA MP, PUGLIESE C, BUCCIONI A AND BADII M. 2002. Field bean (Vicia faba var. minor) as a protein feed for growing lambs with and without protected lysine and methionine supplementation. Ital J Anim Sci 1: 229-238.

ARNHOLD E. 2013. easyanova: Analysis of variance and other important complementary analyzes. 2013. R package version 2.1. Available at: <http://CRAN.R-project.org/ package $=$ easyanova $>$ Accessed: February $15^{\text {th }} 2013$.

BALDWIN JA, HORTON GMJ, WOHLT JE, PALATINI DD AND EMANUELE SM. 1993. Rumen-protected methionine for lactation, wool and growth in sheep. Small Rumin Res 12: 125-132.

BURKE JM AND APPLE JK. 2007. Growth performance and carcass traits of forage-fed hair sheep wethers. Small Rumin Res 67: 264-270.

Cartaxo FQ, Cezar MF, Sousa WH, Gonzaga Neto S, Pereira Filho JM AND Cunha MGG. 2009. Características quantitativas da carcaça de cordeiros terminados em confinamento e abatidos em diferentes condições corporais. Rev Bras Zootec 38: 697-704.

Crosby MM, MENDOZA GD, MELGOZA LM, BÁRCENA R, PLATA FX AND ARANDA EM. 2006. Effects of Bacillus licheniformis amylase on starch digestibility and sheep performance. J Appl Anim Res 30: 133-136.

FERNANDES MAM, MONTEIRO ALG, POLI CHEC, BARROS CS, RIBEIRO TMD AND SILVA ALP. 2008. Características das carcaças e componentes do peso vivo de cordeiros terminados em pastagem ou confinamento. Acta Sci Anim Sci 30: 75-81.

Furusho-GARCIA IF, COSTA TIR, ALMEIDA AK, PEREIRA IG, ALVARENGA FA AND LiMA NLL. 2010. Performance and carcass characteristics of Santa Ines pure lambs and crosses with Dorper e Texel at different management systems. Rev Bras Zootec 39: 1313-1321.

GARRETT WN. 1980. Factors influencing energetic efficiency of beef production. J Anim Sci 51: 1434-1440.

IBGE - Instituto BRAsileiro DE Geografia E ESTATÍSTICA. 2010. Produção pecuária municipal 2010 [online]. Available: <http://www.ibge.gov.br/home/ estatistica/economia/ppm/2010/default.shtm>. Access: February, $15^{\text {th }} 2013$.

IMIK H AND GUNLU A. 2011. Effects of sodium bicarbonate, polyethylene glycol and methionine added to rations with sorghum (Sorghum vulgare) in fattening lambs on growth performance, wool quality and some blood biochemical markers. Rev Med Vet 162: 432-439.

MACEDO CAB ET AL. 2007. Comportamento ingestivo de ovinos recebendo dietas com diferentes níveis de bagaço 
de laranja em substituição à silagem de sorgo na ração. Rev Bras Zootec 36: 1910-1916.

MILLER GL. 1959. Use of Dinitrosalicylic Acid reagent for determination of reducing sugar. Anal Chem 31: 426-428.

NRC - NATIONAL ReseARCH COUnCIL. 2001. Nutrient requirements of dairy cattle. $7^{\text {th }}$ ed., Washington: National Academic Press, 408 p.

NRC - NATIONAL Research Council. 2007. Nutrient requirements of small ruminants. Washington: National Academic Press, 384 p.

OBEIDAT BS, ABDUllah AY, AWAWDEH MS, KRIDLI RT, TITI HH AND QUDSIEH RI. 2008. Effect of methionine supplementation on performance and carcass characteristics of Awassi ram lambs fed finishing diets. Asian-Australasian J Anim Sci 21: 831-837.

R Development Core Team. 2012. R: A language and environment for statistical computing. R Foundation for Statistical Computing, Vienna, Austria. Available at: $<$ http://www.R-project.org/> Access: December $16^{\text {th }} 2012$.

Rojo-Rubio R, MENDOZA GD, GONZALEZ SS, LANDOIS L, BARCENA R AND CROSBY MM. 2005. Effects of exogenous amylases from Bacillus licheniformis and Aspergillus niger on ruminal starch digestion and lamb performance. Anim Feed Sci Technol 124: 655-665.
SILVA JR A. 2009. Interações químico-fisiolóficas entre acidificantes, probióticos, enzimas e lisofosfolipídios na digestão de leitões. Rev Bras Zootec 38: 238-245.

SILVA LF AND PIRES CC. 2000. Avaliações quantitativas e predição das proporções de osso, músculo e gordura da carcaça em ovinos. Rev Bras Zootec 29: 1256-1260.

SOARES BC, SOUZA KDS, LOURENÇO JR JB, Silva AGM, Ávila SC, Kuss F, ANDRADE SJT, RAIOL LCB AND Colodo JCN. 2012. Desempenho e características de carcaças de cordeiros suplementados com diferentes níveis de resíduo de biodiesel. Arq Bras Med Vet Zootec 64: $1747-1754$.

SUN ZH ET AL. 2007. Effects of dietary methionine and lysine sources on nutrient digestion, nitrogen utilization, and duodenal amino acid flow in growing goats. J Anim Sci 85: 3340-3347.

TRICARICO JM, JOHNSTON JD AND DAWSON KA. 2008. Dietary supplementation of ruminant diets with an Aspergillus oryzae a-amylase. Anim Feed Sci Technol 145: 136-150.

Wiese SC, White CL, Masters DG, Milton JTB AND DAVIDSON RH. 2003. The growth performance and carcass attributes of Merino and Poll Dorset $\times$ Merino lambs fed rumen-protected methionine (Smartamine ${ }^{\mathrm{TM}}-\mathrm{M}$ ). Australian J Agric Res 54: 507-513. 
